\title{
BARRED OWL NEST RECORD FOR ALBERTA
}

by Edgar T. Jones, 6115-141 Street, Edmonton

What appears to be the first authentic record of a Barred Owl (Strix varia) nest in Alberta was found by Rod Burns and myself at Edmonton on May 28, 1966. Although the Barred Owl in recent years has been believed to breed in Alberta, no actual nest site has been reported (Salt and Wilk, Birds of Alberta, revised ed., 1966).

The nest site, as is typical for the Barred Owl, was in a hole 28 to 30 feet above the ground in a recently deceased black poplar. A Saskatchewan nest, which was discovered on June 4, 1961, was 18 feet high in a black poplar stub (Blue Jay, 19:114115). The nest cavity which was about 18 inches in depth, appeared to have been used for several years for in it there was a thick layer of mouse remains. The nest contained three young, approximately half-grown and just commencing to feather. The owlets were banded. When the tree was first climbed, one adult sat silently in an adjacent tree making no attempt to drive off the intruder, or to decoy

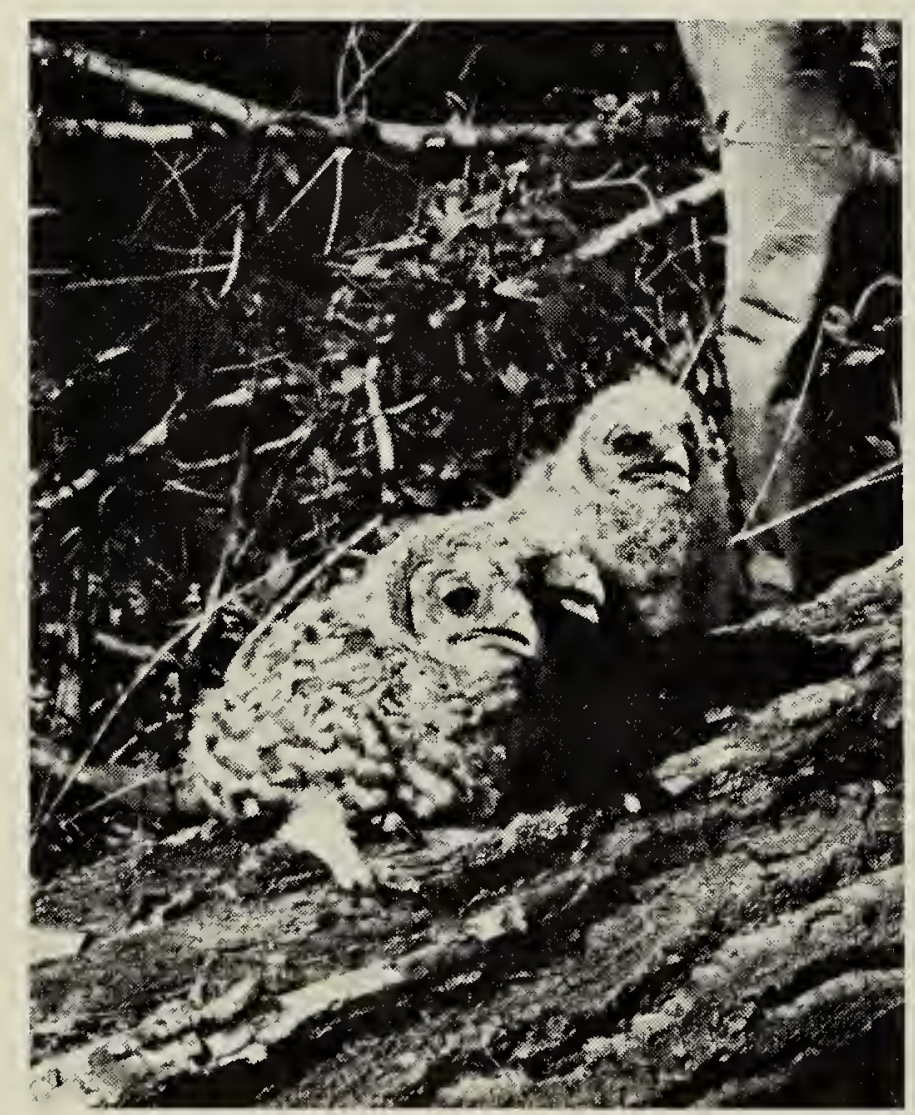

Photo by Edgar T. Jones Young Barred Owls the intruders away by "broken-wing acts" such as Long-eared and Great Horned Owls sometimes perform. These birds have probably been nesting in this cavity for at least the last four years, for I have heard and seen them regularly during this time.

It is worth noting that within a 500 yard circle of the Barred Owl nest site we found a Great Horned Owl nest with young and a Cooper Hawk nest with three eggs.

There is little doubt in my mind that the Barred Owl nests regularly in the more heavily wooded areas of Alberta. The species has been seen by me in the Timeau, Jasper, and Rocky Mountain House areas, and evidence of their presence has also been seen in several other regions. Several specimens have also been sent in over the past few years. Undoubtedly, other nests will be found in Alberta as more interested naturalists explore the remote sections of the province.

\section{A BAY-BREASTED WARBLER NEST RECORD FOR ALBERTA}

by Edgar T. Jones, Edmonton

The Bay-breasted Warbler (Dendroica castanea) was added to Alberta's breeding list when a nest with three young was found and photographed near Skeleton Lake in the Boyle region on July 9, 1965. Rod Burns of Edmonton, a keen youngster, was on this trip with me when this record was established. I am sure the bird is not too rare a breeder in the more remote sections of the province, for I band a number of them during the fall migration each year at Edmonton. In the fall of 1965, for example, I banded four which were trapped on my property. This species is listed by Salt and Wilk (Birds of Alberta, revised ed., 1966) as a scarce summer resident across the northern half of Alberta. 